NidhomulHaq: Jurnal ManajemenPendidikan Islam

TerakreditasiRistekdikti: 28/E/KPT/2019

DOI: https://doi.org/10.31538/ndh.v5i3.1085

http://e-journal.ikhac.ac.id/index.php/nidhomulhaq
E-ISSN: 2503-1481

Hal: 446-458

\title{
CURRICULUM IMPLEMENTATION DURING COVID-19 PANDEMIC IN SOCIOLOGICAL PERSPECTIVE
}

\author{
Windu Widagdo'), Isa Anshori' ${ }^{2}$ \\ ${ }^{1}$ Muhammadiyah Sidoarjo University \\ email: winduwidagdo@gmail.com \\ 2 Islam Negeri Sunan Ampel University \\ email: isaanshori67@gmail.com
}

\begin{abstract}
Since the appearance of the positive cases COVID-19 for the first time in Indonesia in March 2020, the number of confirmed positive cases and deaths has continued to increase to this day. The Covid19 pandemic has had a systemic impact on all aspects of life, especially in education sector. In the event of a disaster emergency, education must continue with access and education services carried out in accordance with the conditions and centered on the fulfillment of children's educational rights and educational services carried out online. Based on this, the government has switched the learning and teaching process, which was originally in school to be at home or Home Study (BDR). In implementing this government policy, it is necessary to implement the school curriculum during the COVID-19 pandemic. This research aims to find out the curriculum implementation during covid-19 pandemic in sociological perspective. The research method used is qualitative method, this was to find information on curriculum implementation in the form of planning, implementation and assessment of curriculum at Muhammadiyah 1 Sidoarjo Junior High School during the covid-19 pandemic. The results obtained from this research, that is the implementation of the curriculum is very important in regulating learning during the covid-19 pandemic that must continue to run despite the social distancing implementation.
\end{abstract}

Keywords: Curriculum, Covid-19 Pandemic, Sociology

\section{INTRODUCTION}

Since the appearance of the positive cases COVID-19 for the first time in Indonesia in March 2020, the number of confirmed positive cases and deaths has continued to increase to this day. The Covid-19 pandemic has had a systemic impact on all aspects of life, especially in education sector. To overcome the effects of COVID19, the Indonesian government has taken a policy of Large-Scale Social Restrictions (PSBB), in which this policy directly affects communal activities or activities that require a large group of people somewhere. One example of the affected education unit is institutions. So that the institution is closed and the learners do the learning process from home or learn from home (BDR).

In the event of a disaster emergency, education must continue with access and educational services carried out in accordance with the conditions and centered on the fulfillment of children's educational rights. This refered to the Minister of Education and Culture Regulation (Permendikbud) No. 72 of 2013 about the Implementation of Special Service 
Education and in accordance with Minister of Education and Culture Regulation (Permendikbud) No. 33 of 2019 about the Implementation Program for Disaster Safe Education Unit (SPAB),

In implementing this government policy, it is necessary to implement the school curriculum during the COVID-19 pandemic. According to Law No. 20 of 2003 the Curriculum means "a set of plans and regulations about the aims, content and material of lessons and the method employed as the guidelines for the implementation of learning activities to achieve given education objectives"

In order for the purpose of education during the COVID-19 pandemic to be achieved, in the education unit must have a managed curriculum program, because the curriculum has a central position in the entire educational process in order to achieve the educational objectives that have been formulated. the curriculum must be prepared immediately to produce an efficient and effective education during the COVID-19 pandemic. Curriculum is a teaching program that includes the activities of planning, implementation and assessment of the curriculum. Other than that, in the learning process can not be separated from the role of a teacher. Teachers play a role in managing the learning process so that directions and objectives can be achieved.

Sidoarjo is the largest area infected with the COVID-2019 pandemic in East Java after Surabaya city. This is supported by the condition of Sidoarjo as a buffer city for the activities and economy of surabaya area.

Sidoarjo local government also implemented a policy of limiting physical contact. In Sidoarjo a task force was formed to provide quick response information about COVID-19. All these activities are carried out by local governments who must be quick and responsive because the rate of spread of sufferers is increasing every day.

One of the Sidoarjo Government's attention is to enforce all decisions of the minister of education and culture. So, this has an impact on all schools to transfer the learning and teaching process that was originally in the school to be in their respective homes, as well as education services carried out online.

Muhamadiyah 1 Sidoarjo Junior high school as an educational institution affected by the COVID-19 pandemic is also trying to conduct activities to support Learning and Teaching activities (KBM) from home. Muhammadiyah 1 Sidoarjo Junior High School is trying its best to keep developing the school curriculum. This effort was part of the school curriculum development 
strategy. This development is carried out so that students and parents can monitor the development of education during the Learning from Home (BDR) period.

This journal aims to find out the implementation of the covid-19 pandemic curriculum in sociology perspective at Muhammadiyah 1 Sidoarjo Junior High School as the affected school

\section{LITERATURE REVIEW}

\section{Curriculum}

Based on law no. 20 Year 2003, curriculum is a guideline for the implementation of learning activities to achieve certain educational objectives that include a set of plans, arrangements regarding the purpose of content and subject matter. The curriculum management scope is an integral part of Education Unit Level Curriculum (KTSP) and School Based Management (MIS) includes planning, organizing the implementation and evaluation of the curriculum. At the Education Unit Level Curriculum activities prefer to realize and relevanize between the national curriculum competency standards / basic competencies with the needs of the district and the condition of the school concerned, so that curriculum is a curriculum that integrates with learners and with the environment in which the school is located.
Based on the statement according to Rusman (2018:17), in general some activities related to curriculum management functions can be stated as follows:

Managing Curriculum Planning

as a reference for curriculum development at the school education unit level, the central government needs to formulate and establish a national standard curriculum (standards of competence and basic competencies).

Managing Curriculum Implementation

Curriculum implementation is a form of actualization of the curriculum that has been planned. Learning activities carried out by teachers and students, that is to achieve the curriculum objectives that have been set is a form of curriculum implementation.

Managing the Implementation of Curriculum Evaluation

Evaluation of the curriculum formally contained in Article 57 of Law Number 20 Year 2003 about the National Education System as the basis for the implementation of curriculum evaluation. The contents of Article 57 paragraph (1), evaluation is carried out in order to control the quality of education nationally as a form of accountability for the implementation of education to interested parties", Then, paragraph (2) 
states "Evaluation is carried out on students, institutions, and educational programs in formal and non-formal pathways for all levels, units, and types of education.

Managing The Implementation

Arrangement of Graduation and Criteria

Determination .

The implementation of the Education Unit Level Curriculum requires the acquisition of complete learning outcomes (mastery learning). The criteria for passing grade must be properly understood by the headmaster and teachers so that there is no mistake in making a wrong decision. This activity is a continuation of curriculum evaluation and learning activities that need to be done objectively, integrity, and comprehensively. Because of that, to determine the passing grade criteria needs to be done appropriately in accordance with the applicable provisions.

Managing The Development of Learning Media, Teaching Materials, and Learning Resources

Community-based experiental learning must be developed strategically in order to produce students who are integrated with the environment. Therefore, the teaching materials learned by students should not only be based on textbooks, but rather need to use and develop various teaching materials through media and learning resources that are in accordance with the topic of discussion.

Managing Extracurricular Development.

Extracurricular activitie is educational activities outside the subjects and counseling services is to help the development of students in accordance with their potential, talents, needs, and interests) through activities specifically organized by educators and or education personnel who are capable and authorized in schools.

\section{Corona Pandemic / COVID 19}

Corona is a virus that causes acute pneumonia. Coronavirus first case was reported in Wuhan, Hubei Province, China. In December 2019, there were Acute Respiratory Distress Syndrome (ARDS) patients. From December 2019 to January 2020 the cases increased and spread widely between countries.

Human Coronavirus is a group of disease-causing viruses that cause pandemics, such as MERS and SARS. In the past, this group has inflicted a loss as socioeconomicly and psychologically. But recent research has led to mutations in viral genes. Researchers are trying to explore and study this group of viruses for better management. 
The initial strain, 2019 novel coroanvirus (2019-nCoV) became Coronavirus Disease (COVID 19) caused by severe acute respiratory syndrome coronavirus-2 (SARS CoV-2). WHO officially announced the disease on February 11, 2020.

The virus can be transmitted from human to human and has been widespread in China and all parts of the world and other territories. WHO announced COVID 19 as a Pandemic on March 12, 2020. Its transmission is relatively fast, has a high mortality rate and the absence of definitive therapy causes a high risk in a country. Recent developments with clinical trials still have not found effective therapies for treatment or prevention. The various treatments provided have not had a significant effect to control the spread and cure of COVID 2019.

The spread of the disease has a serious impact on an infected country. The occurrence of crises in socio-economic and health until death is one of the impacts. COVID 19 is affecting some serious economic setbacks. This case affects disruptions in the fields of economics, politics, and education.

Some of the steps and programs that have been done medically to reduce and slow the fall of more victims are the determination of Physical distancing. This activity is appropriate and proven effective if supported by the authorized Government. This pandemic can be suppressed by the awareness of physical distance. These consequences can decrease the exposure of both active and carrier patients. Other than that, there are several recommendations, such as delaying travel to reduce crowds, production programs of local medical equipments, restrictions on the movement of people. Programs to improve social togetherness that is - solidarity, responsibility, and cooperation - as a result of the practice of Physical distancing.

Prevention that has been done by some countries include the existence of social distancing and staying at home. This program is carried out to minimize physical contact between people. Other than that, a Clean and Healthy Lifestyle (PHBS) is also forced to reduce the risk of exposure to this virus.

But some experts have stated that this is a natural phenomenon, which appears as a form of natural balance. But the human toll in this pandemic is not over. The wisdom that can be taken by researchers is that the planet "Earth" rests and heals itself from the damage caused by humans.

Indonesia as one of the affected countries has made several decisions in the 
face of COVID 2019. The government implemented the contents of Law No. 6 year 2018 about Health Quarantine. Public health emergency is an extraordinary public health event characterized by the spread of infectious diseases and / or events caused by nuclear radiation, biological pollution, chemical contamination, bioterrorism, and food that poses health hazards and potentially spread across regions or crosscountry. This implementation carried out with consideration of the size of the threat, epidemiological, support of effectiveness resources, operational technical, economic, cultural, social, and security considerations.

Consequently, Indonesia is implementing several programs that must be implemented in the community to deal with the COVID 2019 pandemic. Some steps include:

Social distancing/Physical distancing program efforts are carried out to reduce the rate of exposure and transmission of COVID 2019. Other than that, there is an effort to predict the scenario of physical distancing program. Government intervention after closing entertainment venues and the enactment of Work From Home (WFH) suppressed the rate of human interaction. The faster the rate of suppression of interaction between people, the more detained new positive cases per day.

Rules for The Home Quarantine, Regional Quarantine, Hospital Quarantine. Implementation of PSBB (Large-Scale Social Restrictions). This activity is a limitation of certain activities of a resident in a region suspected of being infected or contaminated with the disease in such a way as to prevent the possible spread of disease or contamination. The purpose of this activity is to prevent the spread of public health emergency disease, in this case is COVID 19 disease. This activity consists of restrictions on religious activities and restrictions on activities in public places/facilities, holidays of schools and workplaces;. PSBB is proposed and implemented by the Governor / Regent / Mayor through the Task Force for the Acceleration of Handling COVID 19 and must be through the approval of the Central Government (President) based on epidemiological considerations, the amount of threat, effectiveness, resource support, operational technical, political, economic, social, cultural, defense and security considerations.

\section{The Impact of the COVID 19 Pandemic} on Education in Indonesia

As of March 13, 2020, UNESCO recorded 61 countries declaring school 
closing activities and as many as $421,388,462$ students affected by access to elementary to higher education. But UNESCO is also working with the country to ensure continuity of learning for all students.

The impact of the 2019 COVID Pandemic is also experienced by the education sector in Indonesia. The government has issued a policy not to do activities outside the home. All work is carried out at home, including teaching and learning activities (KBM). Quarantine policies are also issued to reduce human interaction to reduce the rate of COVID 2019 patients. Some other policies of the Minister of Education and Culture include:

1) cancellation of UN 2020, including the 2020 Skills Competency test for Vocational High School,

2) Learning from Home (BDR) process,

3) Implementation for the School Examination,

4) Passing Class Process that does not consider PAS in the form of tests, assignments, online tests or remote assessment of portfolios and achievements that have been obtained.

5) New Learner Acceptance mechanism (PPDB) in accordance with health protocols.
The impact on all campuses, schools and student centers was closed to reduce crowd levels. The Government of Indonesia and related institutions must provide an educational process for their students during BDR (Home Learning) activities. The Education and Culture Ministry has set up several policies to support online learning activities. Education and Culture Ministry developed a distance learning application that was socialized with the "Learning House" program. This portal can be accessed on this website learning.kemdikbud.go.id. Some features that can be accessed by students and teachers, that is learning resources, digital classes, virtual laboratories and problem banks. Other than that, the Ministry has collaborated with 7 (seven) Androidbased learning platforms including Smart Classes, Zenius, Your School, Quipper, Google Indonesia and Microsoft. The platform provides learning resources that can be accessed with free of charge by teachers and students to improve learning process. The Home Learning Program was also launched as an alternative if students and educators 
are not able to access the online learning platform optimally. This collaboration was broadcast by Televisi Republik Indonesia (TVRI) starting on Monday, April 13, 2020 at 08.00 WIB. Merdeka Belajar program launched by the Education Ministry and can be implemented with the applicable health protocols. This program can run in the midst of pandemic conditions, self-quarantine needs, Physical and Social Distancing. Some platforms are already invited to cross the existing barriers.

Some educational institutions have to build policies so that activities and learning process can run despite the limitations. However, this will be a problem for educational institutions that are unprepared and do not have an online academic system. What's more, Teacher Resources that do not yet understand the learning system with online applications. The problem is coupled with a bad internet connection both in range and signal. But online learning and Elearning are bringing new directions and innovations in Indonesia, as 75\% of students have done E-learning simultaneously during the COVID 19 pandemic.

This phenomenon presents challenges and opportunities for teachers to creatively develop interesting, innovative and fun learning methods. This innovative learning uses online media as a learning medium. This learning is not limited to time and place. References obtained by students also vary. On the other hand, teachers experience the transformation of conventional-traditional learning models into multimedia-based presentations. What's more is the 2013 curriculum requires teachers to conduct learning processes based on Information and Communication Technology. Global problems have forced teachers to transform rapidly.

Teachers are required to be able to master the information because it is basically the teacher who provides information to students, of course with the hope this can transmit the expected character by transmitting mindsets and attitudes that show the value of maturity. Teachers must also be able to master the development of science and technology that develops in society.

Traditional and routine learning that gives rise to teacher and student interactions in the classroom and outside the classroom has shifted into distance learning. However, eventually this leads to learning with a lack of a touch of humanism. Education of Community Norms and Religious Norms as one of the touches of humanism that can 
not be replaced by tools, but can be filled with the existence of teachers. Based on the statement stated by Isa Anshori, online learning has many disadvantages, that is preparation in infrastructure and facilities used in learning and impacting students who are not ready for online learning because not all students have facilities used for online learning.

\section{RESEARCH METHODS}

This research used qualitative approach. According to (Laxy, 2014) qualitative approach is "the data collected is not in the form of numbers but rather the data from interview manuscripts, field records of personal documentation, memo records and other official documents. Qualitative research is more concerned with the process". The reason the author has chosen qualitative research is that the author wants to see how the planning, implementation and evaluation of curriculum during the covid 19 pandemic. The research location was Muhammadiyah 1 Sidoarjo Junior High School, which is planned from 2 to 4 November 2020. The subjects in this research were the principal, deputy head of curriculum section, students and student's guardian. To obtain data in this research, the author used several data collection techniques, such as: 1. Observation, 2. Interview, 3. Documentation. To process the data of the research results, the author carried out the following steps: 1. Data collection (display data) 2. Data reduction 3. Data presentation 4. Verify the data.

\section{RESULTS AND DISCUSSIONS}

Based on regulation letter number 15 year 2020 on guidelines for the implementation of learning from home in the emergency period of the spread of corona virus disease (covid-19) and Regulation Letter of the Education and Culture Minister Number 4 Year 2020 on the Implementation of Education Policy in the Emergency Period of the Spread of Corona Virus Disease (COVID 19) then teaching and learning activities are carried out from home.

\section{Planning}

To prepare for learning with the concept of Learning from home (BDR) Muhammadiyah 1 Sidoarjo Junior High School : Develop effective weeks, semester programs, year programs and lesson schedules during the covid-19 pandemic.Preparation of infrastructure to implement BDR program, that is: website, e-elearning and other supporting facilities.

Training or workshop of teachers and employees in learning online.

Other than that, the headmaster said that although learning during the covid-19 pandemic is not face-to-face / done online, 
learning does not always emphasize on theory / knowledge only, but aspects of attitudes and skills must also be conveyed to learners and learning must remain meaningful where learning must instill collaboration, communication, creativity and critical thinking in learners.

\section{Implementation}

Methods and Media implementation of Learning From Home (BDR) carried out with Distance Learning (PJJ) which is divided into 2 (two) approaches:

1. online distance learning

Media and Learning Resources For Online Distance Learning at home can use:
a. Internet-connected laptops or PC
b. Smart Phone connected to the internet
c. Other social media such as WA, Instalgram, Facebook and youtube
d. Website atau e-learning
e. Google Classroom and Google Form
f. Quizizz

2. Offline distance learning

Offline Learning Media and Learning Resources. Offline home learning during BDR can be done with:
a. Television, the example is Home Learning Program through TVRI;

b. radio;
c. self-study modules and worksheets;
d. printed teaching materials; And
e. instrument and learning media from objects and the surrounding environment.

3. Combination of online and offline media Based on a statement by vice principal of the curriculum section, in the implementation of PJJ, the education unit can choose the approach (online or offline or a combination of both) in accordance with the availability and readiness of facilities and infrastructure. For the implementation at Muhammadiyah 1 Sidoarjo Junior High School, they used a combination of online and offline.

\section{Assessment}

For assessment of learning in Muhammadiyah 1 Sidoarjo Junior High School during the covid-19 pandemic in the form of practice questions, tasks, daily replays, Midterm Assessment (PTS) and Final Assessment (PAS), they used elearning facilities, google classroom, google form, kahoot and quizizz.

To keep all students motivated during the covid-19 pandemic, the school held a virtual online competition on each program and rewarded the students who won the champion. 
Other than that, according to the survey results obtained in the field, student guardians are quite enthusiastic in supporting online learning during the covid19 pandemic with the acquisition of actively participating students as many as $84.2 \%$ of students, $79.1 \%$ of student guardians support in online learning. In its implementation, online learning is running $8.8 \%$ very well, $36.7 \%$ is well and $37.8 \%$ is quite well. In total, $83.3 \%$ of parents said that the implementation of the covid-19 pandemic curriculum at Muhammadiyah 1 Sidoarjo Junior High School was going well.

\section{Sociological Perspectives in Covid-19}

\section{Education}

According to the results of the survey obtained in the field, there has been a gap in the implementation of the curriculum during the covid-19 pandemic at Muhammadiyah 1 Sidoarjo Junior High School. This is because there are some parents who were not supporting the implementation of curriculum during the covid 19 pandemic. The reason they were not supporting is the absence of supporting tools such as smartphones, laptops, internet access and credits. Other than that, learning becomes ineffective because of the absence of parental assistance / supervision at home due to both their parents' work.
According to sociological perspective, from the problems at above, there has been a social grouping, that is the curriculum during the covid-19 pandemic that can not run effectively due to the absence of availability of supporting facilities owned by students and the absence of parental assistance / supervision. Social grouping can be based on various things, such as gender, age, education, economy, religion, employment and others. Based on the statement by max weber there are three social factors whose inequality of ownership causes social layering, that is wealth, prestige, and power. People of different levels of prosperity will also be different patterns or lifestyles and ideals, as well as expectations. This is similiar with people of different levels of power and status. The three components are not separated from each other. The rich often have good status and greater power. After all, there is a tendency that if one of the three components is already owned, the other will soon follow.

\section{CONCLUSION}

Based on the research, it was concluded that the planning, implementation and assessment of the curriculum during the covid-19 pandemic is very needed. Good and effective curriculum planning, implementation and assessment will have a 
positive impact on the school, students and parents even in the event of an emergency during the covid-19 pandemic. Infrastructure in the implementation of curriculum during the covid-19 pandemic is needed for online learning, so it can run well. Similarly, the need for mentoring and supervision from parents when studying at home, this is because teachers can only monitor the condition of students from afar. It requires good cooperation between the school and the parents so that online learning can run more effectively.

But it is undeniable that the implementation of the curriculum during the covid-19 pandemic has a negative impact, especially for students who do not have infrastructure and are far from parental supervision in their implementation, and this resulting in social grouping. However, with the planning, implementation and assessment of the curriculum during the covid-19 pandemic that is well prepared, at least the children's right to get an education can be realized.

\section{REFERENCES}

Adiwikarta, S. (2016). Sosiologi Pendidikan. Bandung : PT. REMAJA ROSDAKARYA.

Isa Anshori, Zahro'ul Illiyyin, Dampak Covid-19 terhadap Proses Pembelajaran di MTs Al-Asyhar Bungah,
Gresik. Islamic Manajement: Jurnal Manajemen Pendidikan Islam, 3 (2), 31 Juli 2020

http:/ /dx.doi.org/10.30868/im.v3i2.80 3,http://jurnal.staialhidayahbogor.ac.id Lindex.php/jim/article/view/803

Kemendikbud. "Data Pokok Pendidikan Dasar dan Menengah Direktorat Jenderal Pendidikan Anak Usia Dini, Pendidikan Dasar dan Pendidikan Menengah Kementerian Pendidikan dan Kebudayaan.” https://dapo.dikdasmen.kemdikbud.go. id/sp/3/050211, 2020. Available: https:/ / dapo.dikdasmen.kemdikbud.go. id/sp/3/050211.

. "SURAT EDARAN NOMOR 4 TAHUN $2 \mathrm{O} 2 \mathrm{O}$ TENTANG PELAKSANAAN KEBIJAKAN PENDIDIKAN DALAM MASA DARURAT PENYEBARAN CORONA VIRUS DISEASE (COVID-19)." Jakarta: Kementerian Pendidikan Dan Kebudayaan, 2020.

Kemendikbud, and Kementerian Pendidikan dan Kebudayaan. "Surat Edaran Nomor 4 Tahun 2020 Tentang Pelaksanaan Kebijakan Pendidikan Dalam Masa Darurat Penyebaran Coronavirus Disease (COVID 19)." Jakarta: Kementerian Pendidikan Dan Kebudayaan, 2020. 
KemenkoPMK, Kementerian Koordinator

Bidang Pembangunan Manusia dan

Kebudayaan Republik Indonesia.

"Karantina Wilayah." Jakarta:

Kementerian Koordinator Bidang

Pembangunan Manusia dan

Kebudayaan Republik Indonesia, 2020.

Available:

https://www2.kemenkopmk.go.id/info rmasi-publik/berkala.

KemensesnegRI. "Keputusan Presiden

Republik Indonesia No. 12 Tahun 2020

Tentang Penetapan Bencana Non Alam

Penyebaran Corona Virus Disease 2019

(COVID 19) sebagai Bencana

Nasional." Indonesia No. 12 Tahun

2020 Tentang Penetapan Bencana Non

Alam Penyebaran Corona Virus

Disease 2019 (COVID 19) sebagai

Bencana Naisonal. Jakarta:

Kementerian Sekretariat Negara

Republik Indonesia, 2020. Available:

https://jdih.setneg.go.id/viewpdfperatu

ran/P18857/Keppres Nomor 12

Tahun 2020.

Kumar, Satyendra. "Corona Virus

Outbreak: Keep Physical Distancing,

Not Social Distancing” (n.d.).

Lee, Sunghak et al. "Impact of Corona Virus

Outbreak Towards Teaching and

Learning Activities in Indonesia."

Journal of Chemical Information and
Modeling 53.9 (2012): 1689-1699.

Available:

http://dx.doi.org/10.1016/j.tws.2012.0

2.007 .

MA, Jahangir. "Coronavirus (COVID-19):

History, Current Knowledge and Pipeline Medications." International Journal of Pharmaceutics \& Pharmacology 4.1 (2020): 1-9.

Moleong, L. J., (2014). Metodologi Penelitian Kuantitatif. Bandung : PT REMAJA ROSDAKARYA

Rusman.(2018).Manajemen Kurikulum.Depok : PT RAJA GRAFINDO PERSADA. 